\title{
El "Rubén Darío Criollo", de Diego Manuel Sequeira
}

GIEMPRE nos había parecido extraño que ningún escritor centroS americano se hubiera empeñado en escribir un libro que revelara cuáles eran los conocimientos de Rubén Darío antes de su salida de Nicaragua para ir a Chile. De los muchos libros que existen, casi todos se basan en la autobiografía del mismo Darío, sin que los autores hagan el menor intento de acertar en la verdad del asunto que tratan. Son famosos los errores en que incurrió el propio Darío, en cuanto a la narración de su vida.

Máximo Soto Hall y Alemán Bolaños escribieron sus libros de primera mano; los dos fueron muy buenos amigos del poeta. Desgraciadamente no incluyeron muchos datos significativos que pudieran haber ayudado al biógrafo de Darío.

Armando Donoso y Arturo Torres-Rioseco continuaron la labor de indagar datos desconocidos, aquél con buen éxito; aunque se deslizaron algunos errores en su obra, el profesor Torres-Rioseco hizo un enorme esfuerzo, para precisar las fechas exactas en cuanto a las poesias y los acontecimientos de la vida de Darío. Hasta la fecha, su libro es el mejor que tenemos, porque analizó el desarrollo del poeta, comenzando con sus primeros versos, para llegar hasta los finales. No era de esperar que el estudio de Torres-Rioseco fuese el último, ni se hallase libre de errores. El autor lo admite de antemano, y espera que otros hagan todo lo posible para obtener los datos que él no pudo lograr.

En Nicaragua, el señor Diego Manuel Sequeira, abogado educado en París, acaba de terminar un estudio sobre el poeta nicaragüense; en él nos relata detalladamente la vida de Darío, desde su naci- 
miento hasta el día de su salida para Chile. La obra se intitula $R u b e ́ n$ Dario criollo (Raíz y medula de su creación poética). Es un magnífico libro; ha sido elegantemente impreso en Buenos Aires y patrocinado por el Instituto Cultural Argentino-Nicaragüense.

Con mucha paciencia y cuidado, el doctor Sequeira buscó y encontró las primeras referencias a Darío, en la prensa de Nicaragua y otros países de Centroamérica. Su estudio representa cinco años de labor, y cuando le visitamos en Managua, en 1943, apenas tenía completos los tres primeros capítulos. Con la ayuda de varios de sus compatriotas, que le prestaron muchas cartas inéditas, consiguió escribir el libro. Es difícil que alguien, en el futuro, tenga más autoridad que él.

Para los críticos, lo más interesante, a mi modo de ver, serán los poemas y artículos que marcan la evolución del poeta desde sus primeros ensayos. Lo que pronosticó el profesor Torres-Rioseco, se ve apoyado ahora por las investigaciones de Sequeira, aunque naturalmente no se pueden hallar modelos de las complicadas pautas de los versos y de la mejor poesía de Darío. Pero es cierto, como lo demuestra el doctor Sequeira, que Darío conocía bien la poesía española, desde la más antigua hasta la de aquellos días.

Como había afirmado Torres-Rioseco, Darío modeló su estilo conforme al de cada poeta que leía, cambiando o añadiendo lo que le daba la gana. El doctor Sequeira afirma también que Darío tenía un amplio conocimiento de los poetas franceses; de manera que es muy probable, a pesar de lo que dice el profesor Torres-Rioseco, que Darío asimilara influencias francesas desde muy temprano, en su carrera lírica.

En cuanto a la controversia que aún subsiste, sobre si influyó Gavidia en el poeta, sólo dice Sequeira: “E1 18 de ese mismo mes [septiembre de 1884] recibió Rubén de El Salvador una carta de Francisco Gavidia, con quien había estrechado relaciones literarias y de amistad, a través de las cuales Rubén recibió de Gavidia la iniciación en el uso del exámetro griego y la devoción a los parnasianos franceses" (p. 132). Según el profesor Torres-Rioseco, fué Darío y no Gavidia quien comenzó a emplear el exámetro. Sea lo que fuere, este último siempre ha dicho que él y no Darío fué quien llevó a cabo la citada innovación.

No es posible mencionar todos los puntos interesantes que contiene el libro. Sí es dable aludir, en cambio, a las correcciones de 
muchas fechas concernientes a la vida de Darío. Su primera poesía fué publicada por José Dolores Gámez - no Gómez, como aparece en el libro de Torres-Rioseco-, el 26 de junio de 1880, y la última de esa época, el 25 de junio de 1886, cuando ya había partido para Chile, lo cual ocurrió el 5 de junio de 1886. Llegó Darío a la República chilena el 23 de junio y no el 24 de julio, según afirmación de Raúl Silva Castro que cita Torres-Rioseco.

Lo importante es que tenemos una verdadera historia de Darío, respecto a su trabajo poético en Nicaragua durante los primeros 19 años de su vida. El estudio demuestra claramente que el poeta se hallaba, desde entonces, bien preparado; conocía la literatura española e hispanoamericana y había demostrado que sabía escribir y también criticar, con juicio no superado después; es decir, que era un escritor completo.

Debemos gratitud al doctor Sequeira por su pulcro trabajo, que completa nuestro conocimiento del gran poeta de Nicaragua. Sólo hubiéramos deseado que nos diese más amplias opiniones sobre varias cuestiones polémicas y que hubiera seguido las indicaciones del profesor Torres-Rioseco, porque entonces podría haber ampliado la obra de éste, hasta dar término, definitivamente, a las controversias.

Martin E. ERICKSon, Louisiana State University, Baton Rouge, Louisiana. 
